OPEN ACCESS

Edited by:

Sonia Chamizo,

University of Almería, Spain

Reviewed by:

Yuanyuan Zhao,

Beijing Forestry University, China Emilio Rodriguez Caballero,

University of Almería, Spain

${ }^{*}$ Correspondence:

Mei Yong

yongmei2012@imnu.edu.cn

Specialty section:

This article was submitted to

Conservation and Restoration

Ecology,

a section of the journal

Frontiers in Ecology and Evolution

Received: 06 February 2021

Accepted: 20 July 2021

Published: 23 August 2021

Citation:

Yong $M$, Shinoda $M$,

Nandintsetseg N, Bi L, Gao H and

Wang $Y$ (2021) Impacts of Land

Surface Conditions and Land Use on Dust Events in the Inner Mongolian

Grasslands, China.

Front. Ecol. Evol. 9:664900

doi: $10.3389 /$ fevo.2021.664900

\section{Impacts of Land Surface Conditions and Land Use on Dust Events in the Inner Mongolian Grasslands, China}

\author{
Mei Yong ${ }^{1 *}$, Masato Shinoda ${ }^{2}$, Banzragch Nandintsetseg ${ }^{2,3,4}$, Lige Bi ${ }^{5}$, Hailin Gao ${ }^{6}$ and \\ Yingshun Wang ${ }^{7}$ \\ ${ }^{1}$ College of Geographical Science, Inner Mongolia Normal University, Hohhot, China, ${ }^{2}$ Graduate School of Environmental \\ Studies, Nagoya University, Nagoya, Japan, ${ }^{3}$ Information and Research Institute of Meteorology, Hydrology \\ and Environment, Ulaanbaatar, Mongolia, ${ }^{4}$ School of Arts and Sciences, National University of Mongolia, Ulaanbaatar, \\ Mongolia, ${ }^{5}$ Inner Mongolia Meteorological Service, Hohhot, China, ${ }^{6}$ Meteorological Bureau of Xilinguole, Xilinhot, China, \\ ${ }^{7}$ Xilinhot National Reference Climatological Station, Xilinhot, China
}

Aeolian processes in temperate grasslands (TGs) are unique because the plant growth-decay cycle, soil water, and land-use interactions affect the seasonal and inter-annual changes in dust events. Land-use types in Inner Mongolian TGs are unique (settled grazing and grass mowing) compared with those in Mongolian TGs. Since 2003, land use has been controlled by grassland protection legislation, which is intended to prevent desertification and dust storms. In this study, we used process-based ecosystem (DAYCENT) and statistical modeling, along with dust event observations from March to June of 1981-2015, to (1) identify critical land surface factors controlling dust emissions (vegetation components, live grass, standing dead grass, litter, and soil moisture) at typical and desert steppe sites in Inner Mongolia and (2) estimate the impact of controlled land-use legislation on dust events. The DAYCENT model realistically simulated the dynamics of the observed vegetation components and soil moisture in 2005-2015. At both sites, similar significant correlations were obtained between spring dust events and wind speed or a combination of all surface factors that retained anomalies (memory) from the preceding year. Among the surface factors, vegetation was a critical factor that suppressed dust in Inner Mongolian TGs, similar to that in Mongolian TGs. In the desert steppe, standing dead grass had the strongest memory and was significantly correlated with dust events, whereas no significant correlations were observed in the typical steppe. This suggests that, in a typical steppe region, heavy grazing and mowing result in few dead grasses, thereby inhibiting the prevention of dust events. Moreover, the simulations of dust events under controlled (light grazing) and uncontrolled (heavy grazing) land-use conditions demonstrated that the grassland protection legislation reduced the occurrence of dust events in typical and desert steppe sites by 25 and 40\%, respectively, since 2003 .

Keywords: dust events, DAYCENT model, vegetation components, soil moisture, land use, mowing, Xilingol Grassland

Abbreviations: TG, Temperate grassland; SW, Soil water; AGDM, Aboveground dead mass. 


\section{INTRODUCTION}

The arid and semi-arid regions of East Asia, including temperate grasslands (TGs) in Mongolia and Inner Mongolia, are the main source regions of Asian dust (Natsagdorj et al., 2003; Wang et al., 2008; Lee and Sohn, 2011). Asian dust events influence cloud formation (Huang et al., 2006), precipitation (Creamean et al., 2013), the Earth's radiation budget (Bat-Oyun et al., 2012), and the global dust cycle (Uno et al., 2009), which affects ecosystems (e.g., land degradation), air pollution (Heft-Neal et al., 2020), and climate (Kok et al., 2018). Moreover, strong dust events threaten human and animal health through air pollution and economic losses, and disrupt social and economic activities in both the source and downwind areas (Shao and Dong, 2006; Lee et al., 2014; Kashima et al., 2016).

Over recent decades, dust events have become increasingly severe in Mongolian TGs because of the combined effects of climate change and human-induced land degradation (Kurosaki et al., 2011; Nandintsetseg and Shinoda, 2015; Nandintsetseg et al., 2021). However, the occurrence of dust storms in northern China has been decreasing in recent years owing to climate change (Wang et al., 2008; Zhu et al., 2008; Liu et al., 2020) and dust storm-control projects (Wang et al., 2010; Wu et al., 2013; Tan and Li, 2015). Quantitative evaluations on the impacts of human activity and dust control measurements on dust events provide a scientific basis for formulating reasonable future landuse policies. Generally, the TGs in Inner Mongolia and Mongolia have similar climates and vegetation types; however, land uses in Inner Mongolia are unique (such as for settled grazing and grass mowing for hay). In response to increasing food demands, specifically increasing livestock product demands, the grazing management policies in Inner Mongolia have changed since the early 1980s, which has greatly affected the ecological environment (Li et al., 2007).

In general, there are two major factors controlling dust emissions, one is erosivity, which is mainly affected by strong winds, and the other is erodibility, which is affected by land surface parameters, including vegetation coverage, soil water (SW), and land-use patterns (such as mowing and grazing) (United Nations Environment Programme, 1997). Recent studies have reported that strong winds mainly cause dust events in desert and grassland regions, while land surface parameters are the critical factors that cause dust events in grassland regions (Kurosaki and Mikami, 2005; Li et al., 2006; Shinoda et al., 2010; Kimura, 2012; Lee and Kim, 2012; Wu et al., 2016; Zhao et al., 2018). Land uses, such as continuous grazing, hay cutting (mowing), and afforestation, are critical elements that affect dust occurrence by changing the land surface conditions (such as soil properties and vegetation coverage) in grasslands (Hoffmann et al., 2016). Continuous long-term high-intensity grazing and trampling directly affects vegetation cover, height, and biomass (Liu et al., 2017; Munkhtsetseg et al., 2017). Hay making is also an important part of grassland management and provides winter fodder. However, it also removes a large amount of biomass from the grassland and directly affects the surface protection layer (Giese et al., 2013).
Previous research on the impacts of grazing and hay cutting on the land surface has mainly utilized remote sensing monitoring and field investigations. Satellite monitoring analyses have used the normalized difference vegetation index (NDVI) to elucidate the impacts of livestock numbers on vegetation under different land-use policies ( $\mathrm{Li}$ et al., 2012). The NDVI and enhanced vegetation index time series have also been used to detect grassland hay cutting in Europe (Andrej et al., 2015). Previous field investigations and lab experiments have reported that the grazing intensity in Inner Mongolian grasslands affects the balance of soil organic matter and surface roughness, which influences vegetation height and coverage, thereby affecting dust emissions (Hoffmann et al., 2008a,b; Liu et al., 2017). Feng and Zhao (2011) successfully combined ecological models and remote sensing to monitor the impacts of grazing intensity on vegetation. Kurosaki et al. (2011) found that the presence of dead leaves during the spring could increase the threshold wind speed, thereby reducing the dust events. This dead leaf hypothesis cannot be widely observed or monitored by satellite observation, however, Nandintsetseg and Shinoda (2015) recently combined land surface memory and modeling to give support to this theory. In addition, Yang et al. (2016) and Wu et al. (2020) analyzed the quantitative contributions of human activity and climate change to the recovery of grassland vegetation net primary productivity. However, a limited number of studies have focused on longterm land-use policies and quantitatively evaluated the impact of grazing and mowing on dust in Inner Mongolian TGs.

In this study, we aimed to (1) identify the critical land surface factors that influence dust events in the Inner Mongolian TGs, and (2) quantitatively estimate the impacts of long-term land use controlled by grassland protection legislation on dust events. Based on the results obtained in Mongolia with similar natural conditions (Nandintsetseg and Shinoda, 2015), we used the process-based DAYCENT ecosystem model (Parton et al., 1998) to estimate the variation of land surface factors under different land-use conditions. Furthermore, we combined the DAYCENT model with the statistical model to simulate the number of dusty days, thereby quantitatively evaluating the human impact. This model can simulate dynamic changes in each vegetation component (standing dead grass, live grass, and litter) and in SW under changing environmental conditions and historical human activity. To the best of our knowledge, this study is the first to use a process-based ecosystem model to quantitatively estimate human impacts on dust emissions in China under grassland protection legislation conditions.

\section{DATA AND METHODS}

\section{Study Area}

The study area was the Xilingol Grassland, including the northern Otindag Sandy Land, which is located windward of Beijing (China). This area comprises the main dust source region in northern China and has been a source of concern in recent years. The study area covers a typical steppe (Xilinhot station, $43.95^{\circ} \mathrm{N}$, $116.12^{\circ} \mathrm{E}$ ) and a desert steppe (Erlianhot station, $43.65^{\circ} \mathrm{N}$, $\left.111.97^{\circ} \mathrm{E}\right)$. The typical steppe has a semi-arid climate, and the 
desert steppe has an arid climate, where in the richness, heights, coverage, and yields of grass were significantly lower than those of typical grassland. Dust events generally occur in the study area at the beginning of March (after the soil thaws), continue through May, and peak in April (Kurosaki and Mikami, 2004; Zou and Zhai, 2004; Gou et al., 2010). Moreover, this area is sensitive to changes in land surface conditions (frozen soil, snow cover, and vegetation coverage) (Han et al., 2011; Shinoda and Nandintsetseg, 2011).

Observations of vegetation and SW were collected at the Xilinhot and Erlianhot stations (Figure 1). At Xilinhot station, the average annual precipitation was $264 \mathrm{~mm}$ during 1981-2010, which was concentrated during the summer (May-August, $203.6 \mathrm{~mm}$ ), while the annual mean temperature was $3.0^{\circ} \mathrm{C}$, with a maximum of $21.6^{\circ} \mathrm{C}$ in July and a minimum of $-18.8^{\circ} \mathrm{C}$ in January. The annual average wind speed was $3.7 \mathrm{~m} / \mathrm{s}$, and days with strong winds were concentrated during the spring (average of $4.0 \mathrm{~m} / \mathrm{s}$ ). The typical soil types are calcic chernozems and chestnuts (Hoffmann et al., 2008a), and the ground is frozen from late October to late March. Vegetation typically becomes green in late April and withers in mid-September. Erlianhot station is located in an inland area that is drier and warmer than Xilinhot station. The annual rainfall at Erlianhot station is half that of Xilinhot station $(135 \mathrm{~mm})$ and is concentrated during the summer (May-August, $99.81 \mathrm{~mm}$ ). The annual mean temperature is $4.62^{\circ} \mathrm{C}$, with a maximum of $24.04^{\circ} \mathrm{C}$ in July and a minimum of $-17.78^{\circ} \mathrm{C}$ in January. The average annual wind speed is $3.8 \mathrm{~m} / \mathrm{s}$, and strong windy days are concentrated during the spring (average of $4.41 \mathrm{~m} / \mathrm{s}$ ). The typical soil types are browncalcium soil and chestnut-calcium soil, and the ground is frozen from early November to mid-March. The vegetation growing season is also shorter than at Xilinhot station, beginning in early May and ending in mid-September.

The plant communities of typical steppe regions are mainly herbaceous cool-season communities dominated by $\mathrm{C} 3$ plant species. Natural perennial grasses (Stipa grandis, Stipa krylovii, Leymus chinensis, and Cleistogenes squarrosa) and forbs (Artemisia spp.) are predominant in the Xilinhot area, while natural perennial grasses (Allium mongolicum Regel and Stipa tianschanica Roshev) and small Regel shrubs (Caragana spp.) are predominant in the Erlianhot area (Liu et al., 2004; Chen et al., 2008).

\section{Data}

\section{Meteorological and Dust Data}

Daily meteorological variables (precipitation, and maximum/minimum temperatures) recorded at Xilinhot and Erlianhot stations during 1980-2015 were used as the input parameters for the model. We used synoptic (ground observation data) data for April-June of 2002-2010 from both stations to determine the dust event frequency. In China, meteorological observers have classified dust weather (based on visibility) into "floating dust" (horizontal visibility $<10 \mathrm{~km}$ ), "blowing dust" (1-10 km), "dust storm" (<1 km), and "heavy dust storm"

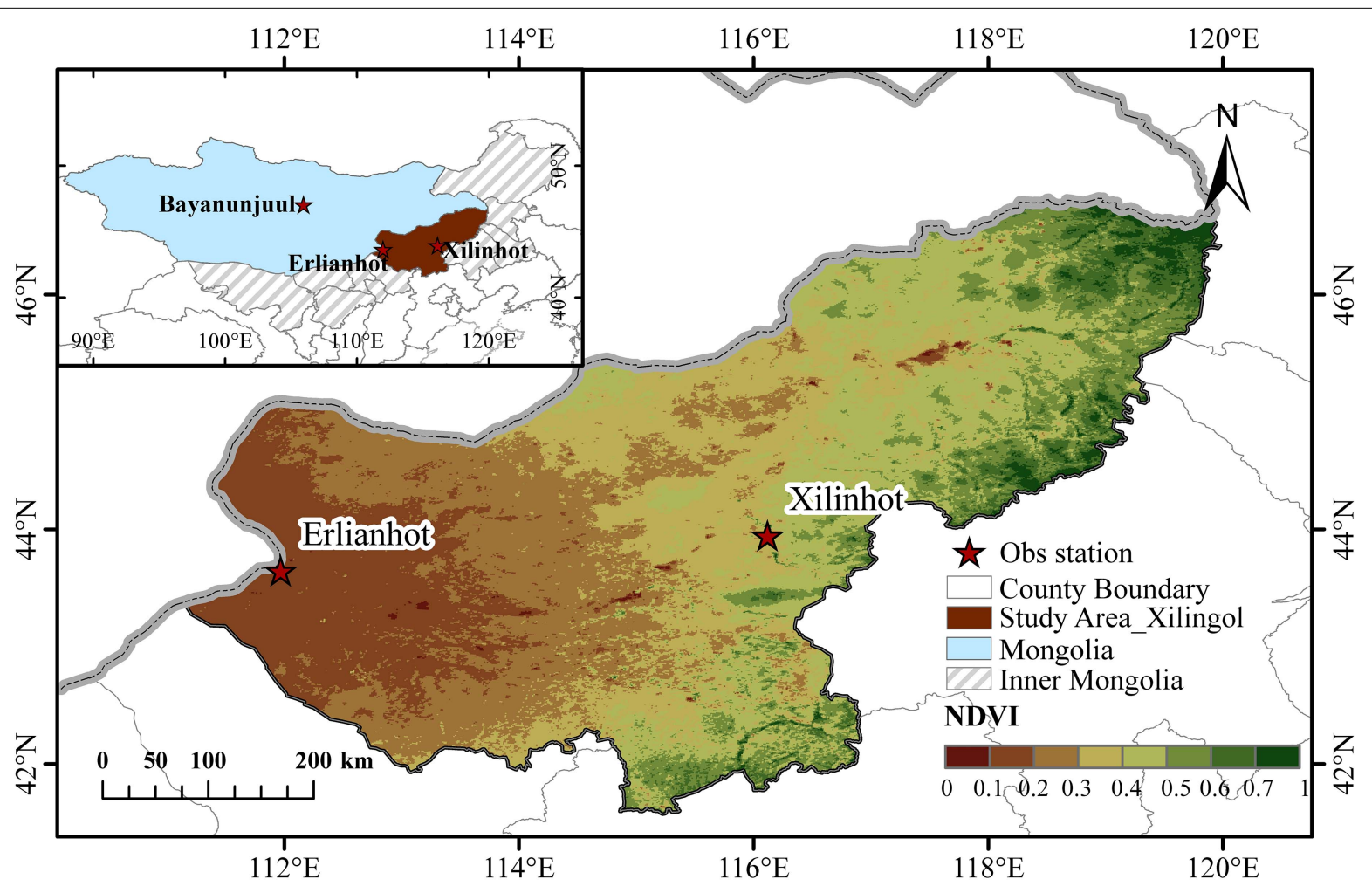

FIGURE 1 | Yearly maximum vegetation condition (2000-2016) across study area of Inner Mongolia by the annual maximum (at the end of August) normalized difference vegetation index (NDVI). 
(visibility decreases to $0.5 \mathrm{~km}$; China Central Meteorological Bureau (CCMB), 1979). These definitions are similar to the World Meteorological Organization for dust storms ( $w w=09$, $30-35,98)$, floating dust (06), and blowing dust $(07,08)$. We included all of the dust events classified as "dust storms," "blowing dust," "floating dust," and "heavy dust storms" in the total dust frequency for each station in this study.

\section{Site Observation Data}

In this study, the DAYCENT model was parameterized and validated using the observed factors (aboveground biomass, SW, and physical/chemical properties) at the Xilinhot and Erlianhot stations. Since April 2004, a 10,000-ha area located $20 \mathrm{~km}$ from the Xilinhot meteorological station has been enclosed by a net fence to protect the vegetation from grazing disturbances. The average stocking rate (number of livestock per ha) during 2004-2015 was approximately 0.66 sheep/ha. According to Sugita et al. (2007) and Nandintsetseg et al. (2018) this grazing intensity can be categorized as moderate. We measured the total aboveground biomass (standing dead grass plus litter and live masses) in the unfenced (grazed) and fenced (ungrazed) areas at the end of each month during May-August (2004-2015) by cutting and weighing all of the aboveground plants within four $1-\mathrm{m}^{2}$ quadrants located randomly in each observation plot (fenced and unfenced). The soil texture and SW were measured at 10-d intervals at both sites (on the 8th, 18th, and 28th day of each month) at depths of $10,20,30,40$, and $50 \mathrm{~cm}$ from March to October (2005-2015). At the Erlianhot station, the aboveground biomass (not observed in the ungrazed area) and SW were measured by the same method as Xilinhot station from 2004 to 2015. The average stocking rate during 2004-2015 in this area was categorized as light grazing ( 0.36 sheep/ha) without mowing. The field-observations of land surface vegetation and soil data from the grazed and ungrazed areas were used for model parameterization, validation, and statistical analyses.

\section{Ecosystem Model Description and Simulation Set-Up Model Description}

We used the DAYCENT model (daily version of CENTURY) to estimate the land surface factors (vegetation components and SW) that prevent dust events in Inner Mongolian TGs. DAYCENT is a process-based ecosystem model that simulates the flows of nutrients, trace gases, and carbon between the soil, plants, and the atmosphere, as well as disturbance factors and human influences, including grazing, harvesting, and fires. DAYCENT also includes soil organic matter, SW, plant productivity, decomposition of dead plant matter, temperature dynamics, and nitrogen gas flux sub-models. The grassland production and land surface sub-models were used to simulate the soil moisture and grassland vegetation component dynamics. The grass sub-model separates the plant biomass into grains, live shoots, standing dead grass, root compartments, surface litter, and belowground litter. Plant growth is controlled by SW, nutrient availability, and temperature. The death rate of the plant compartments is limited by SW, season, temperature, and specific plant senescence factors. The DAYCENT model has been used to simulate grassland vegetation dynamics in Mongolian and Inner Mongolian TGs under various climate change impacts and grazing intensities (Ojima et al., 1993; Feng and Zhao, 2011; Nandintsetseg and Shinoda, 2015). The model can use different grazing intensities (light, moderate, and heavy grazing) to evaluate the impacts of grazing on grassland ecosystems. Among the different grazing intensities, the nutrient content of new shoots increased in relation to residual biomass. Detailed descriptions of the grazing intensity factors can be found in Holland et al. (1992) and Nandintsetseg and Shinoda (2015). The DAYCENT land surface sub-model simulates water flow through the plant canopy, litter, and soil layers $(0-1,1-4,4-15,15-30,30-45 \mathrm{~cm})$ and has been tested extensively (Del Grosso et al., 2011). Soil moisture availability depends on precipitation, potential evapotranspiration (PET), and current SW. Precipitation intercepted by vegetation and litter evaporates at the PET rate. PET was calculated using the Penman (1948) equation. When the daily temperature was below freezing, precipitation accumulated as snow and snowpack. A detailed description of the land surface sub-model can be found in Parton et al. (1998). This model operates on a daily time step and the input variables include: (1) climatic variables (daily maximum and minimum air temperatures and precipitation) and (2) site-specific variables, such as soil properties (texture, depth, $\mathrm{pH}$, bulk density, and, field capacity) and vegetation parameters (potential aboveground production, root depth, initial belowground biomass, fraction of standing dead biomass, live shoots removed by grazing, and aboveground residue removed by mowing) (Table 1 ). In this paper, we simulated the dusty days using DAYCENT output factors, such as SW and vegetation components, under different land-use conditions.

\section{Model Parameterization}

Table 1 shows the primary site parameters, including soil and plant characteristics, meteorological variables, and grazing and harvesting (mowing) conditions. Data from the China Meteorological Data Service Center ${ }^{1}$ were used as the daily meteorological values. First, by repeating the long-term 30-y climate averages (1981-2010), DAYCENT long-term historical simulations were run for $2000 \mathrm{y}$ to determine the balance of soil and vegetation under natural conditions, which were then used as the initial conditions for the verification simulation. Then, the observed daily meteorological data sets from 1981 to 2015 were used to simulate the changes in land surface parameters under different grazing conditions, including heavy grazing during 1981-2002 and moderate grazing with mowing during 2003-2015 in Xilinhot, and moderate grazing during 1981-2002 and light grazing without mowing during 2003-2015 in Erlianhot. The measured soil and vegetation values at each of the sites during 2005-2015 were also used for model validation.

\section{Statistical Analysis of Land Surface Factors and Dusty Days}

In arid and semi-arid grasslands, SW can be used as an effective storage for inter-annual precipitation anomalies and

\footnotetext{
${ }^{1}$ http://data.cma.cn/
} 
TABLE 1 | DAYCENT model input parameters for Mongolian and Inner Mongolian TGsa .

\begin{tabular}{|c|c|c|c|c|c|c|}
\hline \multirow[t]{2}{*}{ No. } & \multirow[t]{2}{*}{ Parameter } & \multirow[t]{2}{*}{ Range $^{b}$} & \multicolumn{3}{|c|}{ Value } & \multirow[t]{2}{*}{ References } \\
\hline & & & $\begin{array}{l}\text { Bayan Unjuul } \\
\text { (Mongolia) }\end{array}$ & $\begin{array}{l}\text { Xilinhot (Inner } \\
\text { Mongolia) }\end{array}$ & $\begin{array}{l}\text { Erlianhot (Inner } \\
\text { Mongolia) }\end{array}$ & \\
\hline 1 & $\begin{array}{l}\text { Potential aboveground monthly } \\
\text { production in temperate grasslands }\end{array}$ & $200-550$ & 300 & 550 & 200 & Measured data \\
\hline 2 & $\begin{array}{l}\text { Optimum temperature }\left({ }^{\circ} \mathrm{C} \text { ) for } \mathrm{C} 3\right. \\
\text { grasses (approximately equal to the } \\
\text { mean temperature of the warmest } \\
\text { month) }\end{array}$ & $10.0-40$ & $15.0\left(v^{\star}\right)$ & 15 & 17 & \\
\hline 3 & $\begin{array}{l}\text { Maximum temperature }\left({ }^{\circ} \mathrm{C}\right) \text { for } \mathrm{C} 3 \\
\text { grasses }\end{array}$ & +20.0 to +50.0 & $32.0\left(v^{*}\right)$ & 32 & 33 & \\
\hline 4 & $\begin{array}{l}\text { Physiological shutdown temperature } \\
\left({ }^{\circ} \mathrm{C}\right) \text { for root death and change in the } \\
\text { shoot/root ratio of grass }\end{array}$ & -5.0 to +5.0 & 2 & 2 & 2 & $\begin{array}{l}\text { Temperate C3 } \\
\text { grasses }^{b}\end{array}$ \\
\hline 5 & $\begin{array}{l}\text { Maximum shoot death rate for grass } \\
\text { under very dry soil conditions (\%) }\end{array}$ & $0.0-1.0$ & 0.2 & 0.2 & 0.2 & \\
\hline 6 & $\begin{array}{l}\text { Fraction of shoots that die during the } \\
\text { senescence month }\end{array}$ & $0.4-1.0$ & 0.95 & 0.95 & 0.95 & \\
\hline 7 & $\begin{array}{l}\text { Maximum root death rate for grass } \\
\text { under very dry conditions }\end{array}$ & $0.0-1.0$ & 0.05 & 0.05 & 0.05 & \\
\hline 8 & Soil layer thickness (cm) & & 30 & 30 & 30 & \\
\hline 9 & Soil pH & $0.0-15.0$ & $6.5\left(\right.$ soil $\left.^{\star}\right)$ & $7.6\left(\right.$ soil $\left.^{\star}\right)$ & $7.8\left(\right.$ soil $\left.^{\star}\right)$ & Measured data \\
\hline 10 & Root depth (cm) & & $40\left(\right.$ soil $\left.^{\star}\right)$ & $40\left(\right.$ soil $\left.^{\star}\right)$ & $40\left(\right.$ soil $\left.^{\star}\right)$ & Measured data \\
\hline 11 & Soil field capacity (fraction) & $0.0-1.0$ & $0.21\left(\right.$ soil $\left.^{\star}\right)$ & $0.19\left(\right.$ soil $\left.^{\star}\right)$ & $0.19\left(\right.$ soil $\left.^{\star}\right)$ & Measured data \\
\hline 12 & Soil wilting point (fraction) & $0.0-1.0$ & $0.07\left(\right.$ soil $\left.^{\star}\right)$ & $0.08\left(\right.$ soil $\left.^{\star}\right)$ & $0.06\left(\right.$ soil $\left.^{\star}\right)$ & Measured data \\
\hline 13 & Soil bulk density $\left(\mathrm{g} / \mathrm{cm}^{3}\right)$ & $0.0-2.0$ & $1.44\left(\right.$ soil $\left.^{\star}\right)$ & $1.5\left(\right.$ soil $\left.^{\star}\right)$ & $1.6\left(\right.$ soil $\left.^{\star}\right)$ & Measured data \\
\hline 14 & Fraction of clay in the soil layer & $0.0-1.0$ & $0.09\left(\right.$ soil $\left.^{\star}\right)$ & $0.16\left(\right.$ soil $\left.^{\star}\right)$ & $0.1\left(\right.$ soil $\left.^{\star}\right)$ & Measured data \\
\hline 15 & Fraction of sand in the soil layer & $0.0-1.0$ & $0.65\left(\right.$ soil $\left.^{\star}\right)$ & $0.74\left(\right.$ soil $\left.^{\star}\right)$ & $0.8\left(\right.$ soil $\left.^{*}\right)$ & Measured data \\
\hline 16 & Fraction of silt in the soil layer & $0.0-1.0$ & $0.24\left(\right.$ soil $\left.^{\star}\right)$ & $0.1\left(\right.$ soil $\left.^{\star}\right)$ & $0.1\left(\right.$ soil $\left.^{\star}\right)$ & Measured data \\
\hline 17 & Initial belowground biomass $\left(\mathrm{g} / \mathrm{m}^{2}\right)$ & & $200\left(v^{\star}\right)$ & $250\left(v^{*}\right)$ & $200\left(v^{\star}\right)$ & Measured data \\
\hline 18 & $\begin{array}{l}\text { Initial relative soil water content } \\
\text { (fraction) }\end{array}$ & & $0.16\left(\right.$ soil $\left.^{\star}\right)$ & $0.16\left(\right.$ soil $\left.^{\star}\right)$ & $0.16\left(\right.$ soil $\left.^{*}\right)$ & \\
\hline 19 & $\begin{array}{l}\text { Precipitation from January through } \\
\text { December }(\mathrm{cm})\end{array}$ & & $d^{*}$ & $d^{*}$ & $d^{*}$ & \\
\hline 20 & Daily minimum air temperature $\left({ }^{\circ} \mathrm{C}\right)$ & & $d^{*}$ & $d^{*}$ & $d^{*}$ & \\
\hline 21 & Daily maximum air temperature $\left({ }^{\circ} \mathrm{C}\right)$ & & $d^{\star}$ & $d^{*}$ & $d^{*}$ & \\
\hline 22 & $\begin{array}{l}\text { Fraction of standing dead biomass } \\
\text { removed by a grazing event }\end{array}$ & $0.0-1.0$ & 0.05 & 0.15 & 0.05 & Holland et al., 1992 \\
\hline 23 & Fraction content of feces & $0.0-1.0$ & 0.25 & 0.25 & 0.25 & $\begin{array}{l}\text { pasture } \\
\text { management }\end{array}$ \\
\hline 24 & $\begin{array}{l}\text { Fraction of live shoots removed by a } \\
\text { grazing event }\end{array}$ & $0.0-1.0$ & 0.3 & 0.5 & 0.3 & \\
\hline 25 & $\begin{array}{l}\text { Fraction of the aboveground residue } \\
\text { that will be removed by moving }\end{array}$ & $0.0-1.0$ & 0 & 0.75 & 0 & \\
\hline
\end{tabular}

${ }^{a} V^{*}$, soil ${ }^{\star}=$ mean parameters related to vegetation type and soil type, respectively, $d^{*}=$ parameters that varied with season .

${ }^{b}$ Century user manual: http://www.nreal.colostat.edu/projects/century/.

influences vegetation growth (Delworth and Manabe, 1988). The inter-annual anomalies of SW and vegetation are preserved during the freezing period from winter to spring as the initial conditions of land surface in the following summer (Shinoda and Nandintsetseg, 2011). To investigate the memory of the interseasonal and inter-annual land surface factors, autocorrelation statistical analyses of plant biomass and SW were applied as a land surface memory index. Memory is defined as the instantaneous lag when the autocorrelation coefficient is lower than the confidence level of $95 \%$ for the sequence (Delworth and Manabe,
1988; Nandintsetseg and Shinoda, 2013). First, the memories of the monthly plant biomass and SW between 1981 and 2015 were investigated. Correlation and multiple regression analyses were then conducted to determine the simultaneous relationships between the spring dusty days and land surface factors. We selected five predictive land surface factors (SW, live and standing dead grasses, litter, and wind speed) to estimate the number of monthly dusty days at both sites from March to June of 2002-2010; these data were compared with those from the Mongolian TGs. As shown in Table 2, we considered each 
land surface variable in the regression model followed by a combination of all the land surface factors.

\section{Modeling Human Impacts on Dust Events}

We assumed that the increasing trend in stocking density during 1981-2002 continued after 2003 at both sites under the scenario without policy controls. Additionally, we assumed that the mowing practice would be the same before and after 2003 (i.e., mowing in Xilinhot and no-mowing in Erlianhot). We then applied a multiple regression model to estimate the number of dusty days using all the controlling factors for the scenarios with (moderate grazing in Xilinhot and light grazing in Erlianhot) and without (heavy grazing) post-2003 policy control. Then, we compared the number of dusty days under both the two scenarios to evaluate the effect of the policy (Table 3 ).

\section{RESULTS AND DISCUSSION}

\section{Model Evaluation}

The DAYCENT model was evaluated using the 10-d SW and monthly aboveground biomass data obtained during 20052015 at Erlianhot (grazing) and Xilinhot (grazing and nongrazing areas with mowing). Figure $\mathbf{2}$ indicates the daily observed and simulated aboveground biomasses (live grass and standing dead grass), SW, and precipitation in the grazed and ungrazed sites during 2005-2015. As shown in Figure 2A, the temporal variations in the modeled SW were simulated well for both Xilinhot $(r=0.74, p<0.01$; RMSE $=2.66$, Relative RMSE $=31 \%)$ and Erlianhot $(r=0.69, p<0.01 ; \mathrm{RMSE}=1.41$, Relative RMSE $=35 \%)$. Seasonally, SW increased after snowmelt and soil thawing, and increased further when the summer monsoon season began. Inter-annually, SW was relatively low during dry years and relatively high during wet years. In the typical steppe, the SW was generally twice as high as that in the desert steppe.

Figures 2B,C show the observed and simulated monthly aboveground biomass in the grazed and ungrazed areas of Xilinhot and Erlianhot, respectively. The simulated biomass patterns for the grazed and ungrazed sites corresponded well with the observed patterns in both regions $(r=0.82$, $p<0.01$; RMSE $=27.59$, Relative RMSE $=33 \%$ for Xilinhot and $r=0.83, p<0.01$; RMSE $=7.43$; Relative RMSE $=28 \%$ for Erlianhot). The seasonal dynamics of the aboveground biomass and onset of spring growth, summer peak, and decay time were also well simulated. However, the model underestimated the summer peak aboveground biomass during the measurement period, particularly during low-production years (dry) in Xilinhot (2005 and 2013) and in Erlianhot (2006, 2010, and 2012). These results are similar to Mongolian TGs (Nandintsetseg and Shinoda, 2015), where

TABLE 2 | Correlation coefficients between spring monthly dust events and their controlling factors during March-June of 2002-2010.

\begin{tabular}{|c|c|c|c|c|c|c|}
\hline & \multirow[b]{2}{*}{ No. } & \multirow[b]{2}{*}{ Predictive variable } & & \multicolumn{3}{|c|}{ Correlation coefficient } \\
\hline & & & & $\begin{array}{l}\text { Xilinhot (typical steppe) } \\
\text { (Inner Mongolia) }\end{array}$ & $\begin{array}{l}\text { Erlianhot (desert steppe) } \\
\text { (Inner Mongolia) }\end{array}$ & $\begin{array}{l}\text { Bayan Unjuul (typical } \\
\text { steppe) (Mongolia) }\end{array}$ \\
\hline \multirow[t]{6}{*}{1} & Individual & Wind speed & (u) & 0.54 & 0.68 & $\underline{0.5}$ \\
\hline & & Soil moisture & $(\mathrm{SW})$ & $-\underline{0.33}$ & -0.13 & -0.25 \\
\hline & & $\begin{array}{l}\text { Vegetation (dead, litter, } \\
\text { and live) }\end{array}$ & & -0.43 & -0.48 & -0.48 \\
\hline & & Standing dead & (Dead) & -0.29 & -0.45 & $-\underline{0.41}$ \\
\hline & & Litter & (Litter) & 0.05 & -0.15 & -0.08 \\
\hline & & Live & (Live) & $-\underline{0.40}$ & -0.29 & -0.26 \\
\hline 2 & Combination & Surface variables & SW, live, dead, litter & -0.43 & -0.55 & -0.58 \\
\hline 3 & & All variables & u, SW, live, dead, litter & 0.62 & 0.71 & 0.83 \\
\hline
\end{tabular}

Single and double underlines indicate significant at the 5 and $1 \%$ levels, respectively.

TABLE 3 | Scenarios of human influence simulation under different land-use conditions before and after dust policy control.

\begin{tabular}{|c|c|c|c|c|}
\hline & & & 1982-2002 (before policy control) & 2003-2015 (after policy control) \\
\hline & & & Land-use condition & Land-use condition \\
\hline & Livestock & Actual & Moderate grazing, mowing & Moderate grazing, mowing (with policy control) \\
\hline \multirow[t]{4}{*}{ Xilinhot } & & Simulate & / & Heavy grazing, mowing (without policy control) \\
\hline & Dusty days & Actual & Site observed & Site observed \\
\hline & & Simulate & Moderate grazing, mowing & Heavy grazing, mowing (without policy control) \\
\hline & Livestock & Actual & Moderate grazing & Light grazing, no mowing (with policy control) \\
\hline \multirow[t]{3}{*}{ Erlianhot } & & Simulate & / & Moderate grazing (without policy control) \\
\hline & Dusty days & Actual & Site observed & Site observed \\
\hline & & Simulate & Moderate grazing & Heavy grazing, no mowing (without policy control) \\
\hline
\end{tabular}



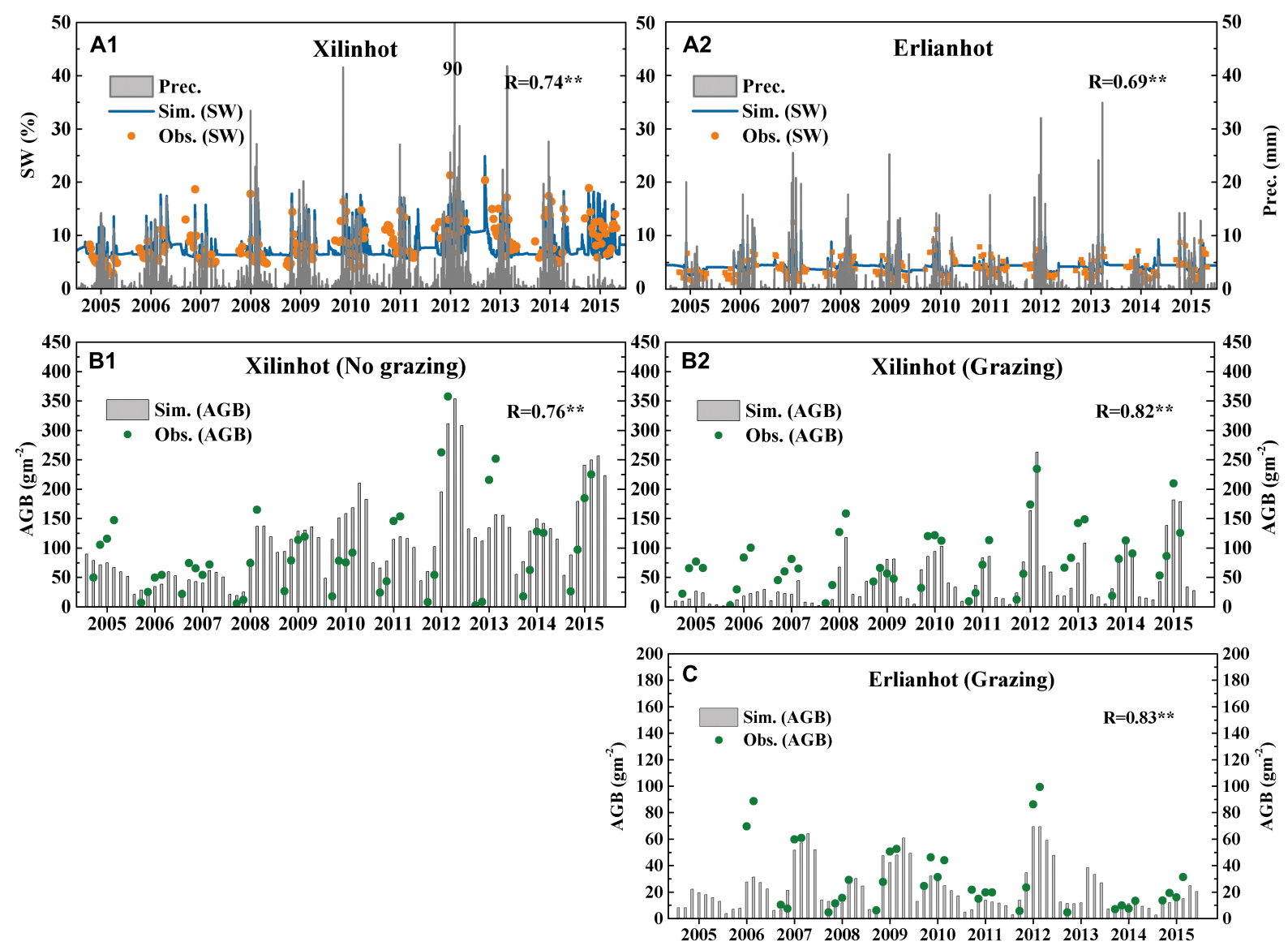

FIGURE 2 | (A) Comparison of daily precipitation (Prec.), 10-day observed (depth $10.0 \mathrm{~cm}$ ) and daily simulated (depth $7.5 \mathrm{~cm}$ ) SW (The maximum value of y-axis precipitation is $90 \mathrm{~mm}$. In order to clearly indicate the SW, the maximum value is limited to $50 \mathrm{~mm}$ ); observed and model simulated aboveground biomass (AGB) in Inner Mongolian Xilinhot station (B) and Erlianhot station (C). ${ }^{* \star}$ Indicates significant at the $1 \%$ level.

the prevalence of annual plant species significantly increased following drought years (Shinoda and Nandintsetseg, 2014). The underestimation of biomass during drought years may be related to changes in species compositions, which the model cannot simulate (Parton et al., 1995). In the Inner Mongolian TGs, the plant species composition may have shifted from perennial to annual species because of drought and overgrazing (Wang et al., 2007; Chen et al., 2008). Furthermore, in steppe regions, the plant biomass in grazed areas was lower than in the ungrazed areas, indicating that grazing enclosures can effectively restore vegetation (Liu et al., 2017). Following the implementation of policies that banned grazing and returned grazing land to grassland in 2003, the number of livestock has been controlled, overgrazing has not occurred again, and the observed biomass of the steppe has stopped decreasing annually.

\section{Seasonal Variations in Dust Events and Their Controlling Factors}

Figure 3A illustrates the climatological seasonal changes (average of 1980-2010) in monthly dust events and average daily wind speeds at the Xilinhot and Erlianhot stations. The dust events in the spring and autumn were enhanced at both sites owing to a combination of low SW, snow cover, vegetation, and strong wind speed (Figures 3B,C). During the winter, the soil was frozen for 5 months, the surface was covered with snow, and the wind speed was low. Therefore, the surface soil was protected from erosion. During the summer, vegetation coverage increased because of increased SW and precipitation, and the wind speed was weaker, which also limited soil erosion. In contrast, during April and May the winds were strong as the study areas are affected by cold fronts associated with cyclones that cause strong Asian dust storms during this season (Natsagdorj et al., 2003; Shao et al., 2011).

Generally, dust events occurred more frequently in Erlianhot than in Xilinhot. This was because Erlianhot has an arid climate (desert steppe). Additionally, it had a lower precipitation (low SW), warmer temperature, and less vegetation coverage than Xilinhot. Plants germinated earlier during the spring in Xilinhot, and the total vegetation biomass was three times higher than that of Erlianhot. However, the amount of standing dead grass was lower in Xilinhot, owing to moderate grazing and mowing.

To examine the land surface memory mechanism in Inner Mongolian TGs, we also calculated the individual autocorrelations (memory) of the SW and aboveground total 

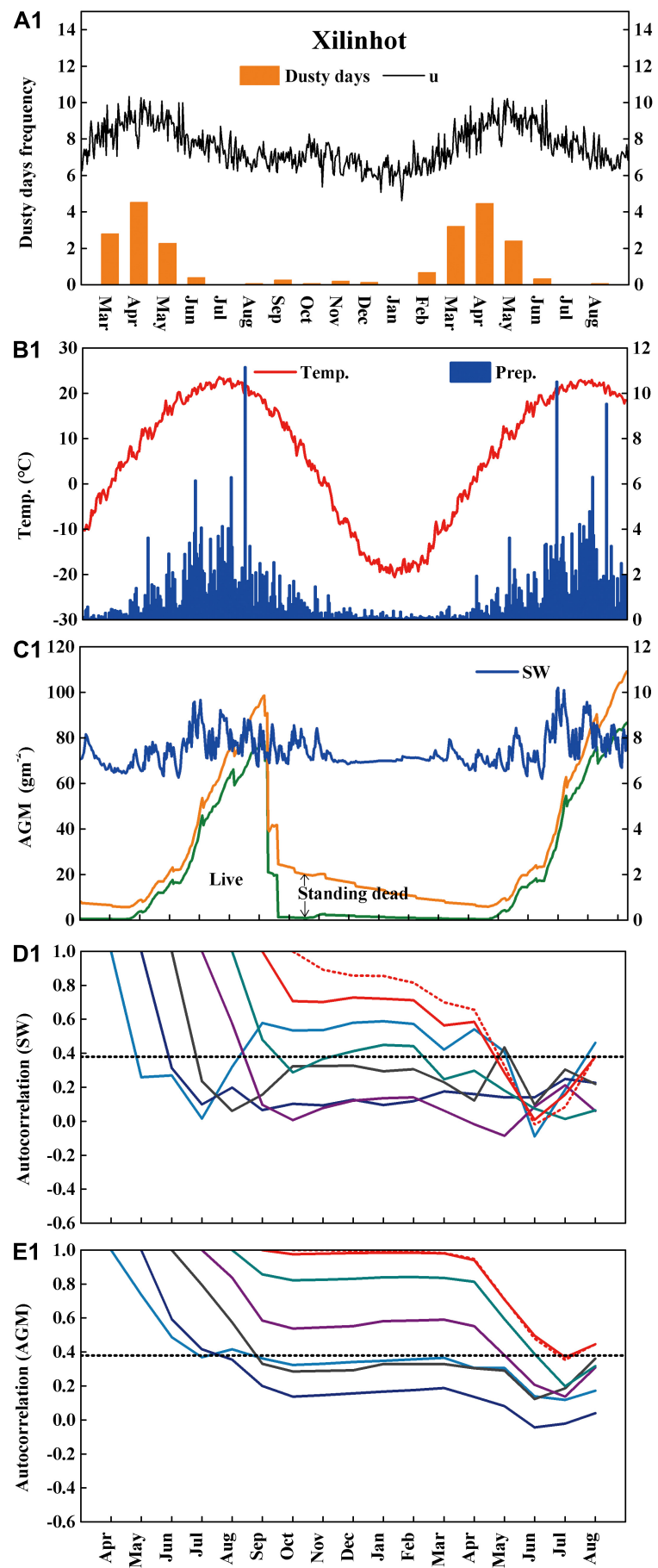
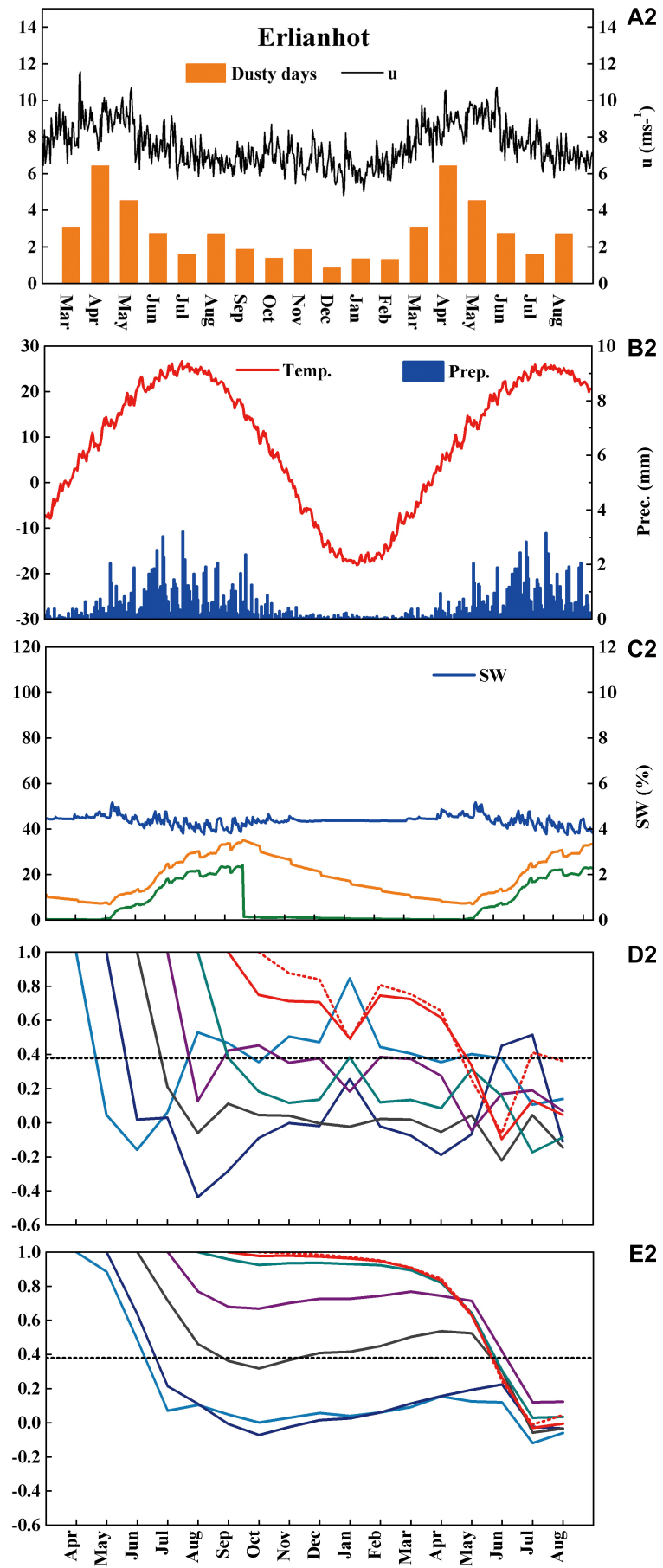

FIGURE 3 | Climatological (1981-2010) seasonal changes in (A) monthly dusty days, frequency and daily mean wind speed (U), (B) daily precipitation (Prec.) and air temperature (Temp.), (C) simulated SW in the $0-45 \mathrm{~cm}$ soil layer and aboveground mass (AGM) in the grazed area, and autocorrelations of (D) SW and (E) AGM. Horizontal dashed lines in (D,E) indicate the 5\% significance level.

mass of live grass, litter, and standing dead grass. Figures 3D,E show that the SW and aboveground mass in September-October or later were significantly $(p<0.01)$ autocorrelated in the subsequent months until June and May in Xilinhot and Erlianhot, respectively. This indicates that vegetation and SW during the spring dust season were related to the corresponding conditions of the preceding year. Standing dead grass exhibited significant $(p<0.05)$ long-term autocorrelations that persisted from July until the following June in Erlianhot because the region was not disturbed by grazing and mowing. In contrast, Xilinhot 
was disturbed by moderate grazing throughout the year and by mowing during early August. Therefore, the vegetation memory from the following September and October lasted until the following spring.

\section{Effect of Land Surface Factors on Dusty Days During Spring}

Multiple regression analysis was conducted (Tables 2, 3) with five possible suppressing factors during the period of MarchJune of 2002-2010 to investigate the critical factors that control the inter-annual variations in dust events using the monthly dusty-day frequency as the dependent variable. Table 2 suggests that, among all the individual variables, the number of dusty days during the spring had the highest correlation with the wind speed and total aboveground masses in both Erlianhot and Xilinhot. Therefore, the total vegetation components in the spring, combined with the memory of the previous summer, are critical land surface factors that suppress dust events in Inner Mongolian TGs. This is similar to the results obtained for Mongolian TGs (Nandintsetseg and Shinoda, 2015). For each vegetation component, a significant correlation between the dust events and the amount of standing dead grass was observed in Erlianhot (Table 2), which may be due to land uses at lower intensity, such as lower grazing and a lack of mowing, in the previous year. In contrast, the spring dusty days were significantly correlated with the amount of live grass and SW in Xilinhot (Table 2). Therefore, owing to early vegetation greening because of the high precipitation and SW, there was a high biomass of live grass during the early growing stage, which greatly affected spring dust events. However, the landuse intensity, with moderate grazing throughout the year and mowing during the autumn, and the lower standing dead grass in the spring did not significantly affect dust (Table 2). This suggests that standing dead grass biomass, live grass biomass, and litter grass cover offer different levels of land surface protection with varying efficiencies. These results indicate that the vegetation cover, particularly standing dead grass coverage under low intensity land use, is a critical factor for preventing dust events in Inner Mongolian TGs.

As shown in Table 2, the correlation coefficients of all land surface element combinations and dusty days at both sites were slightly higher than those of the individual land surface factors. Therefore, the number of dusty days in spring was significantly correlated with wind speed and the total surface factors, which reflected the memories of the previous autumn. According to the multiple regression analyses, the correlation coefficients between the estimated and measured frequencies of dusty days at both sites were significant at the $1 \%$ level for all five factors. Additionally, at Bayan Unjuul (Mongolian TG) and Erlianhot, which are located upwind, the correlation coefficients exceeded that at Xilinhot, which is located downwind.

\section{Effect of Land-Use Policies on Dust Events}

Inner Mongolian TGs experience two different land-use types of grazing and mowing. While pastoral herding is conducted in
Mongolia, sedentary farming is conducted in Inner Mongolia, with grazing in fenced pastures throughout the year. Based on their herding behavior, households conduct different grazing practices in pastures, including seasonal rotational and continuous grazing. In the steppe region, grasses are mowed at the end of August (after vegetation decay) to provide winter feed for livestock.

Figures 4A,C show the inter-annual variations in the grazing intensities for the actual (controlled land use after 2003) and assumed (without controlled land use after 2003) conditions. Following the founding of the Inner Mongolia Autonomous Region, various livestock management policies were adopted, particularly after 1984, when the number of livestock increased sharply. There were three distinct grazing intensity periods that were mainly controlled by these policies. In the 1980s, the number of livestock increased slowly, leading to a change from light to moderate grazing at both sites. In the 1990s, livestock numbers rose rapidly, leading to a shift from moderate to heavy grazing in Xilinhot. During this period, overgrazing-induced land degradation became severe in the Inner Mongolian TGs (Tong et al., 2004). Consequently, the primary functions of the Inner Mongolian TG ecosystems were disturbed by human activity, and this area could shift from a natural dust sink to a dust source (Hoffmann et al., 2008b). Moreover, widespread droughts occurred throughout Asia during 1999-2002, including in Inner Mongolia, and the number of dust events increased significantly (Shinoda and Nandintsetseg, 2014). Since 2003, land use in Inner Mongolian TGs has been controlled by grassland protection legislation to prevent desertification and dust storms. The legislation was intended to reduce livestock numbers to meet the pasture capacities, and ban grazing (animals kept within fenced areas) during the "grazing pause" period. Almost all the grazing areas implemented grazing pauses and significantly reduced their number of livestock. Therefore, since 2003, the actual grazing intensity was maintained at moderate and light levels in Xilinhot and Erlianhot, respectively (Figures 4A,C).

Figures $4 \mathrm{~B}, \mathbf{D}$ show the inter-annual variations in the observed and estimated dusty-day frequencies. The estimates were obtained using a statistical model (multiple regression) based on the actual grazing intensity after 2003. Generally, the simulated and observed dust events exhibited similar inter-annual variations $(r=0.63, p<0.05$; RMSE $=3.61$, Relative RMSE $=42 \%$ and $r=0.73, p<0.05$; RMSE $=6.22$, Relative RMSE $=45 \%$ in the Xilinhot and Erlianhot steppes, respectively) that decreased slightly after 2006. The model underestimated the most frequent observed dust events in 1987, 2000, 2001, and 2006 in Xilinhot, and in 1983, 1984, 2001, and 2006 in Erlianhot, which generally followed drought years with strong winds. Dust events at both sites were likely to not only be affected by the local land surface conditions, but also by dust storms transported from upwind areas.

As shown in Figures $4 \mathbf{B}, \mathbf{D}$, the number of livestock was assumed to increase after 2003 following the same rate as that of the preceding period (red curve; not controlled by policy) under the same mowing or no-mowing practices in Xilinhot and Erlianhot, respectively. A comparison of the scenarios with and 


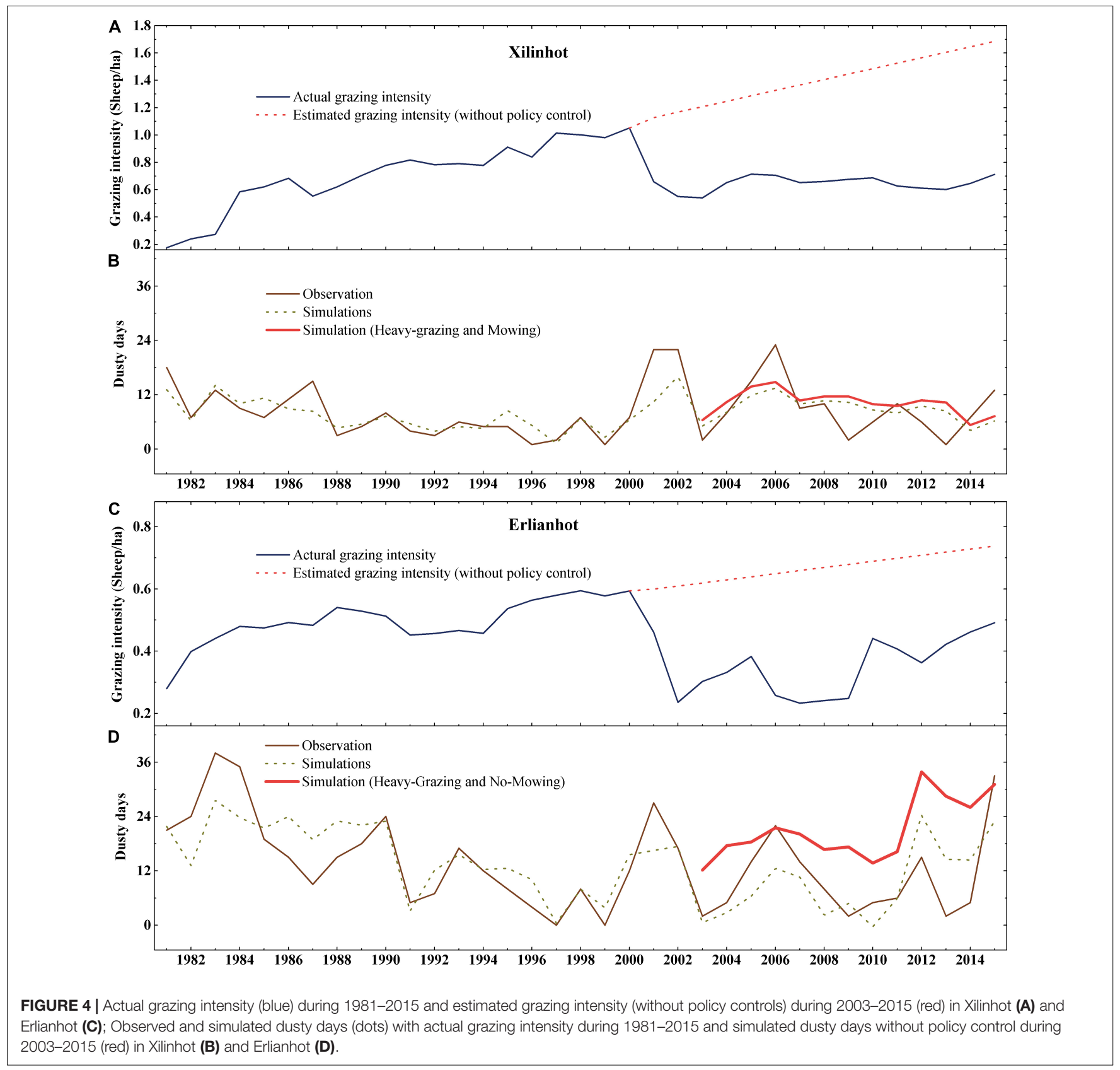

without the policy controls indicated that the policy controls decreased the dust events by $25 \%$ (3 days per month) and $40 \%$ (8 days per month) in Xilinhot and Erlianhot regions during 2003-2015, respectively. This regional difference was influenced by the spring aboveground dead mass (AGDM) (standing dead and litter). That is, smaller differences in the AGDM value for Xilinhot were due to mowing (75\% of total mass) and moderate grazing during the preceding autumn, which reduced the absolute autumn and spring AGDM values. However, in the Erlianhot, light grazing and the lack of mowing increased spring AGDM. Therefore, in steppe areas, the land uses of grass mowing and heavy grazing had negative influences on the occurrence of dusty days and reduced the spring vegetation, which was the primary factor that suppressed dust in Inner Mongolian TGs.

\section{CONCLUSION}

In this study, we investigated the effects of individual grassland surface factors (vegetation components and SW) on the number of dusty days, as well as the impacts of controlled land use under grassland protection legislation on dust events in Inner Mongolian TGs using the DAYCENT ecosystem and statistical models. The vegetation components (aboveground masses of standing dead and live grasses) and SW were measured 
in the grazed and ungrazed areas of typical and desert steppe regions located in an important dust-outbreak region of northern China. Moreover, long-term synoptic observations of dust events during March-June of 1981-2015 were analyzed. Overall, the DAYCENT model adequately simulated the observed land surface vegetation components and SW, which are critical factors controlling dust emissions from the East Asian source region. By applying a statistical model for the land surface components and observed dusty days, the impacts of human-induced land use on dust events were then assessed.

The occurrence of spring dusty days at both sites was significantly correlated with a combination of wind speed and all the land surface elements. Among the surface factors, vegetation was the most critical factor that controlled dust emissions in Inner Mongolian TGs, which is similar to the results obtained in Mongolian TGs. Of the vegetation components, standing dead grasses were significantly correlated with the occurrence of dusty days at the desert steppe site, while live grasses were significantly correlated with the occurrence of dusty days at the typical steppe site. Different land-use intensity, such as grazing and mowing, had major impacts on dust emissions by changing the vegetation and topsoil of the land surface.

A statistical model of local dust events could reasonably simulate the seasonal and inter-annual variations in dust events at both sites during March-June of 1981-2015 ( $r=0.73$, $p<0.01$ for Erlianhot and $r=0.63, p<0.01$ for Xilinhot); however, it underestimated the frequency of observed dust events following drought years. This is likely because these events were mainly composed of dust transported from upwind rather than local dust. Generally, the numbers of estimated and observed dust events have decreased slightly in Inner Mongolian TGs since 2006. Simulated dust events under policy-controlled land use decreased the occurrence of dust events by approximately $25 \%$ (typical steppe) and $40 \%$ (desert steppe) during 2003-2015. The regional difference in the reduction of dusty days was because of the differences in the spring AGDM. That is, the smaller AGDM difference in the typical steppe was due to mowing (70\% of total mass) during the preceding autumn, which reduced the absolute $\mathrm{AGDB}$ in autumn and the following

\section{REFERENCES}

Andrej, H., Matej, M., Marek, H., and Stanislav, D. (2015). Towards Detection of Cutting in Hay Meadows by Using of NDVI and EVI Time Series. Remote Sens. 7, 6107-6132. doi: 10.3390/rs70506107

Bat-Oyun, T., Shinoda, M., and Tsubo, M. (2012). Effects of cloud, atmospheric water vapor, and dust on photosynthetically active radiation and total solar radiation in a mongolian grassland. J. Arid Land 4, 349-356. doi: 10.3724/SP. J.1227.2012.00349

China Central Meteorological Bureau (CCMB). (1979). Standard on Weather Observation. Beijing: Meteorological Press.

Chen, J., Hori, Y., and Yamamura, Y. (2008). Spatial heterogeneity and diversity analysis of macrovegetation in the Xilingol region, Inner Mongolia, China, using the beta distribution. J. Arid Environ. 72, 1110-1119. doi: 10.1016/j. jaridenv.2007.11.013

Creamean, J. M., Suski, K. J., Rosenfeld, D., Cazorla, A., DeMott, P. J., Sullivan, R. C., et al. (2013). Dust and Biological Aerosols from the Sahara and Asia spring. Therefore, appropriate land-use management strategies are vital for suppressing the occurrence of dust events in Inner Mongolian TGs.

\section{DATA AVAILABILITY STATEMENT}

The raw data supporting the conclusions of this article will be made available by the authors, without undue reservation.

\section{AUTHOR CONTRIBUTIONS}

MY field investigated and collected the data, performed the analysis, and wrote the first draft of the manuscript. MS contributed to the conception of the study and helped perform the analysis with constructive discussions. BN contributed to Mongolian data (Bayan-Unjuul) and analysis tools (DAYCENT Modeling), helped perform the analysis with constructive discussions, and edited the manuscript for each level. LB contributed to field observation and data curation. HG and YW contributed to field observation. All authors contributed to the article and approved the submitted version.

\section{FUNDING}

This research was supported by Grants-in-Aid for Scientific Research and the Japan Society for the Promotion of Science (JSPS) Fellows (No. 20H00044), the Joint Research Program of Arid Land Research Center, Tottori University (29C2019), and the National Natural Science Foundation of China (41867070 and 61631011).

\section{ACKNOWLEDGMENTS}

We would like to thank Meteorological Bureau of Xilinguole and Xilinhot national reference climatological station providing us with biomass and soil observation sites and data.

Influence Precipitation in the Western U.S. Science 339, 1572-1578. doi: 10. $1126 /$ science. 122727

Del Grosso, S. J., Parton, W. J., Keough, C. A., and Reyes-Fox, M. (2011). "Special features of the DayCent modeling package and additional procedures for parameterization, calibration, validation, and applications," in Methods of Introducing System Models Into Agricultural Research, eds L. R. Ahuja and L. Ma (Madison, WI: American Society of Agronomy), 155-176.

Delworth, T. L., and Manabe, S. (1988). The influence of potential evaporation on the variabilities of simulated soil wetness and climate. J. Clim. 1, 523-547. doi: 10.1175/1520-04421988001<0523:TIOPEO<2.0CO;2

Feng, X. M., and Zhao, Y. S. (2011). Grazing intensity monitoring in Northern China steppe: integrating CENTURY model and MODIS data. Ecol. Indic. 11, 175-182. doi: 10.1016/j.ecolind.2009.07.002

Giese, M., Brueck, H., Gao, Y., Lin, S., Steffens, M., Kögel-Knabner, I., et al. (2013). $\mathrm{N}$ balance and cycling of inner mongolia typical steppe: a comprehensive case study of grazing effects. Ecol. Monogr. 83, 195-219. doi: 10.1890/120114.1 
Gou, M., Gang-tie, L., Xing, L., and He-jun, Z. (2010). Temporal-Spatial Distribution of Sand Storms in the Xilin Gol Area of Inner Mongolia. Pol. J. Environ. Stud. 19, 309-314. doi: 10.1017/S0032247409008626

Han, L., Tsunekawa, A., and Tsubo, M. (2011). Effect of frozen ground on dust outbreaks in spring on the eastern Mongolian Plateau. Geomorphology 129, 412-416. doi: 10.1016/j.geomorph.2011.03005

Heft-Neal, S., Burney, J., Bendavid, E., Voss, K. K., and Burke, M. (2020). Dust pollution from the Sahara and African infant mortality. Nat. Sustain. 3, 863871. doi: 10.1038/s41893-020-0562-1

Hoffmann, C., Funk, R., Li, Y., and Sommer, M. (2008a). Effect of grazing on wind driven carbon and nitrogen ratios in the grasslands of Inner Mongolia. Catena 75, 182-190. doi: 10.1016/j.catena.2008.06.003

Hoffmann, C., Funk, R., Wieland, R., Li, Y., and Sommer, M. (2008b). Effects of grazing and topography on dust flux and deposition in the Xilingele grassland. Inner Mongolia. J. Arid Environ. 72, 792-807. doi: 10.1016/j.jaridenv.2007. 09.004

Hoffmann, C., Giese, M., Dickhoefer, U., Wan, H., Bai, Y., Steffens, M., et al. (2016). Effects of grazing and climate variability on grassland ecosystem functions in Inner Mongolia: synthesis of a 6-year grazing experiment. J. Arid Environ. 135, 50-63. doi: 10.1016/j.jaridenv.2016.08.003

Holland, E. A., Parton, W. J., Detling, J. K., and Coppock, D. L. (1992). Physiological responses of plant populations to herbivory and their consequences for ecosystem nutrient flow. Am. Nat. 140, 685-706. doi: $10.1086 / 285435$

Huang, J., Minnis, P., Lin, B., Wang, T., Yi, Y., Hu, Y., et al. (2006). Possible influences of Asian dust aerosols on cloud properties and radiative forcing observed from MODIS and CERES. Geophys. Res. Lett. 33:L06823. doi: 10.1029/ 2005GL024724

Kashima, S., Yorifuji, T., Bae, S., Honda, Y., Lim, Y. H., and Hong, Y. C. (2016). Asian dust effect on cause-specific mortality in five cities across South Korea and Japan. Atmos. Environ. 128, 20-27. doi: 10.1016/j.atmosenv.2015. 12.063

Kimura, R. (2012). Effect of the Strong Wind and Land Cover in Dust Source Regions on the Asian Dust Event over Japan from 2000 to 2011. SOLA 8, 8-11. doi: 10.2151/sola.2012-020

Kok, J. F., Ward, D. S., Mahowald, N. M., and Evan, A. T. (2018). Global and regional importance of the direct dust-climate feedback. Nat. Commun. 9:241. doi: 10.1038/s41467-017-02620-y

Kurosaki, Y., and Mikami, M. (2004). Effect of snow cover on threshold wind velocity of dust outbreak. Geophys. Res. Lett. 31, 1-5. doi: 10.1029/ 2003GL018632

Kurosaki, Y., and Mikami, M. (2005). Regional difference in the characteristic of dust event in East Asia: relationship among dust outbreak, surface wind, and land surface condition. J. Meteorol. Soc. Japan 83A, 1-18. doi: 10.1029/ 2003jd003913

Kurosaki, Y., Shinoda, M., and Mikami, M. (2011). What caused a recent increase in dust outbreaks over East Asia? Geophys. Res. Lett. 38, 1-6. doi: 10.1029/ 2011GL047494

Lee, E. H., and Sohn, B. J. (2011). Recent increasing trend in dust frequency over Mongolia and Inner Mongolia regions and its association with climate and surface condition change. Atmos. Environ. 45, 4611-4616. doi: 10.1016/j. atmosenv.2011.05.065

Lee, H., Honda, Y., Lim, Y.-H., Guo, Y. L., Hashizume, M., and Kim, H. (2014). Effect of Asian dust storms on mortality in three Asian cities. Atmos. Environ. 89, 309-317. doi: 10.1016/j.atmosenv.2014.02.048

Lee, J. J., and Kim, C. H. (2012). Roles of surface wind, NDVI and snow cover in the recent changes in Asian dust storm occurrence frequency. Atmos. Environ. 59, 366-375. doi: 10.1016/j.atmosenv.2012.05.022

Li, A., Wu, J., and Huang, J. (2012). Distinguishing between human-induced and climate-driven vegetation changes: a critical application of RESTREND in inner Mongolia. Landsc. Ecol. 27, 969-982. doi: 10.1007/s10980-0129751-2

Li, N., Gu, W., Du, Z., Li, Z., and Song, P. (2006). Observation on soil water content and wind speed in Erlianhot, a dust-source area in northern China. Atmos. Environ. 40, 5298-5303. doi: 10.1016/j.atmosenv.2006.04.019

Li, W., Ali, S. H., and Zhang, Q. (2007). Property rights and grassland degradation: a study of the Xilingol. J. Environ. Manag. 85, 461-470. doi: 10.1016/j.jenvman. 2006.10.010
Liu, J., Wu, D. Y., and Liu, G. J. (2020). Impact of Arctic amplification on declining spring transported dust events in East Asia. Clim. Dyn. 54, 1913-1935. doi: 10.1007/s00382-019-05094-4

Liu, J., Wu, J., Su, H., Gao, Z., and Wu, Z. (2017). Effects of grazing exclusion in Xilin Gol grassland differ between regions. Ecol. Eng. 99, 271-281. doi: 10.1016/j.ecoleng.2016.11.041

Liu, X. Q., Wang, R. Z., and Li, Y. Z. (2004). Photosynthetic pathway types in rangeland plant species from Inner Mongolia, North China. Photosynthetica 42, 339-344. doi: 10.1023/B:PHOT.0000046150.74045.46

Munkhtsetseg, E., Shinoda, M., Ishizuka, M., Mikami, M., Kimura, R., and Nikolich, G. (2017). A livestock trampling function for potential emission rate of wind-blown dust in a Mongolian temperate grassland. Atmos. Chem. Phys. 17, 11389-11401 . doi: 10.5194/acp-2017-94

Nandintsetseg, B., Boldgiv, B., Chang, J., Ciais P., Davaanyam, E., Batbold, A., et al. (2021). Risk and vulnerability of Mongolian grasslands under climate change. Environ. Res. Lett. 16:034035. doi: 10.1088/1748-9326/abdb5b

Nandintsetseg, B., Shinoda, M., Erdenetsetseg, B. (2018). Contributions of multiple climate hazards and overgrazing to the 2009 / 2010 winter disaster. Nat. Hazards 92, 109-126. doi: 10.1007/s11069-017-2954-8

Nandintsetseg, B., and Shinoda, M. (2013). Assessment of drought frequency, duration, and severity, and its impacts on pasture production in Mongolia. Nat. Hazards 66, 995-1008. doi: 10.1007/s11069-012-0527-4

Nandintsetseg, B., and Shinoda, M. (2015). Land surface memory effects on dust emission in a Mongolian temperate grassland. J. Geophys. Res. Biogeosci. 120, 414-427. doi: 10.1002/2014JG002708

Natsagdorj, L., Jugder, D., and Chung, Y. S. (2003). Analysis of dust storms observed in Mongolia during 1937-1999. Atmos. Environ. 37, 1401-1411. doi: 10.1016/S1352-2310(02)01023-3

Ojima, D. S., Dirks, B. O. M., Glenn, E. P., Owensby, C. E., and Scurlock, J. O. (1993). Assessment of C budget for grasslands and drylands of the world. Water Air Soil Pollut. 70, 95-109. doi: 10.1007/BF01104990

Parton, W. J., Hartman, M., Ojima, D., and Schimel, D. (1998). DAYCENT and its land surface submodel: description and testing. Glob. Planet. Change 19, 35-48. doi: 10.1016/S0921-8181(98)00040-X

Parton, W. J., Scurlock, J. M. O., Ojima, D. S., Schimel, D. S., Hall, D. O., and Scopegram Group Members. (1995). Impact of climate change on grassland production and soil carbon worldwide. Glob. Change Biol. 1, 13-22. doi: 10. 1111/j.1365-2486.1995.tb00002.x

Shao, Y., and Dong, C. H. (2006). A review on East Asian dust storm climate, modelling and monitoring. Glob. Planet. Change 52, 1-22. doi: 10.1016/j. gloplacha.2006.02.011

Shao, Y., Wyrwoll, K.-H., Chappell, A., Huang, J., Lin, Z., McTainsh, G. H., et al. (2011). Dust cycle: an emerging core theme in Earth system science. Aeolian Res. 2, 181-204. doi: 10.1016/j.aeolia.2011.02.001

Shinoda, M., Kimura, R., Mikami, M., Tsubo, M., Nishihara, E., Ishizuka, M., et al. (2010). Characteristics of Dust Emission in the Mongolian Steppe during the 2008 DUVEX Intensive Observational Period. Sola 6, 9-12. doi: 10.2151/sola. 2010-003

Shinoda, M., and Nandintsetseg, B. (2011). Soil moisture and vegetation memories in a cold, arid climate. Glob. Planet. Change 79, 110-117. doi: 10.1016/j. gloplacha.2011.08.005

Shinoda, M., and Nandintsetseg, B. (2014). Hotspots of recent drought in Asian steppes. Reg. Environ. Change 14, 103-117. doi: 10.1007/s10113-0130464-0

Sugita, M., Asanuma, J., Tsujimura, M., Mariko, S., Lu, M., Kimura, F., et al. (2007). An overview of the rangelands atmosphere-hydrosphere-biosphere interaction study experiment in northeastern Asia (RAISE). J. Hydrol. 333, 3-20. doi: 10. 1016/j.jhydrol.2006.07.032

Tan, M. H., and Li, X. B. (2015). Does the Green Great Wall effectively decrease dust storm intensity in China? A study based on NOAA NDVI and weather station data. Land Use Policy 43, 42-47. doi: 10.1016/j.landusepol.2014. 10.017

Tong, C., Wu, J., Yong, S., Yang, J., and Yong, W. (2004). A landscapescale assessment of steppe degradation in the Xilin River Basin. Inner Mongolia, China. J. Arid Environ. 59, 133-149. doi: 10.1016/j.jaridenv.2004. 01.004

United Nations Environment Programme. (1997). World Atlas of Desertification, 2nd Edn. Kenya: United Nations Environment Programme. 
Uno, I., Eguchi, K., Yumimoto, K., Takemura, T., Shimizu, A., Uematsu, M., et al. (2009). Asian dust transported one full circuit around the globe. Nat. Geosci. 2, 557-560. doi: 10.1038/ngeo583

Wang, C., Wang, S., Zhou, H., and Glindemann, T. (2007). Effects of forage composition and growing season on methane emission from sheep in the Inner Mongolia steppe of China. Ecol. Res. 22, 41-48. doi: 10.1007/s11284-0060191-9

Wang, X., Xia, D., Wang, T., Xue, X., and Li, J. (2008). Dust sources in arid and semiarid China and southern Mongolia: impacts of geomorphological setting and surface materials. Geomorphology 97, 583-600. doi: 10.1016/j.geomorph. 2007.09.006

Wang, X. M., Zhang, C. X., Hasi, E., and Dong, Z. B. (2010). Has the Three Norths Forest Shelterbelt Program solved the desertification and dust storm problems in arid and semiarid China? J. Arid Environ. 74, 13-22. doi: 10.1016/j.jaridenv. 2009.08.001

Wu, J., Kurosaki, and Du. (2020). Evaluation of climatic and anthropogenic impacts on dust erodibility: a case study in xilingol grassland, china. Sustainability 12:629. doi: 10.3390/su12020629

Wu, J., Kurosaki, Y., Shinoda, M., and Kai, K. (2016). Regional characteristics of recent dust occurrence and its controlling factors in East Asia. SOLA 12, 187-191. doi: 10.2151/sola.2016-038

Wu, Z. T., Wu, J. J., and Liu, J. H. (2013). Increasing terrestrial vegetation activity of ecological restoration program in the Beijing-Tianjin Sand Source Region of China. Ecol. Eng. 52, 37-50. doi: 10.1016/j.ecoleng.2012.12.040

Yang, Y., Wang, Z. Q., Li, J. L., Gang, C. C., Zhang, Y. Z., Zhang, Y., et al. (2016). Comparative assessment of grassland degradation dynamics in response to climate variation and human activities in China, Mongolia, Pakistan and Uzbekistan from 2000 to 2013. J. Arid Environ. 135, 164-172. doi: 10.1016/j. jaridenv.2016.09.004
Zhao, Y. Y., Xin, Z. B., and Ding, G. D. (2018). Spatiotemporal variation in the occurrence of sand-dust eventes and its influencing factors in the BeijingTianjin sand source region, China, 1982-2013. Reg. Environ. Change 18, 24332444. doi: 10.1007/s10113-018-1365-Z

Zhu, C. W., Wang, B., and Qian, W. H. (2008). Why do dust storms decrease in northern China concurrently with the recent global warming? Geophys. Res. Lett. 35:18702. doi: 10.1029/2008GL0 34886

Zou, X. K., and Zhai, P. M. (2004). Relationship between vegetation coverage and spring dust storms over northern China. J. Geophys. Res. 109, 1-9. doi: $10.1029 / 2003$ JD003913

Conflict of Interest: The authors declare that the research was conducted in the absence of any commercial or financial relationships that could be construed as a potential conflict of interest.

Publisher's Note: All claims expressed in this article are solely those of the authors and do not necessarily represent those of their affiliated organizations, or those of the publisher, the editors and the reviewers. Any product that may be evaluated in this article, or claim that may be made by its manufacturer, is not guaranteed or endorsed by the publisher.

Copyright (C) 2021 Yong, Shinoda, Nandintsetseg, Bi, Gao and Wang. This is an open-access article distributed under the terms of the Creative Commons Attribution License (CC BY). The use, distribution or reproduction in other forums is permitted, provided the original author(s) and the copyright owner(s) are credited and that the original publication in this journal is cited, in accordance with accepted academic practice. No use, distribution or reproduction is permitted which does not comply with these terms. 